\title{
Facies Analysis and Depositional Environments of the Late Palaeozoic Coal-Bearing Madzaringwe Formation in the Tshipise-Pafuri Basin, South Africa
}

\author{
Ntokozo Malaza, ${ }^{1}$ Kuiwu Liu, ${ }^{1}$ and Baojin Zhao $^{2,3,4}$ \\ ${ }^{1}$ Department of Geology, University of Fort Hare, Private Bag X1314, Alice 5700, South Africa \\ ${ }^{2}$ WorleyParsons, 54 Melrose Boulevard, Melrose Arch, Johannesburg 2076, South Africa \\ ${ }^{3}$ Department of Environmental Sciences, University of South Africa, P.O. Box 392, Pretoria 0003, South Africa \\ ${ }^{4}$ Department of Geology, Rhodes University, P.O. Box 94, Grahamstown 6140, South Africa
}

Correspondence should be addressed to Ntokozo Malaza; tkmalaza@yahoo.co.uk

Received 30 August 2013; Accepted 3 October 2013

Academic Editors: M. C. Melinte-Dobrinescu and J.-w. Zhou

Copyright (c) 2013 Ntokozo Malaza et al. This is an open access article distributed under the Creative Commons Attribution License, which permits unrestricted use, distribution, and reproduction in any medium, provided the original work is properly cited.

\begin{abstract}
The late Palaeozoic coal-bearing Madzaringwe Formation of the Karoo Supergroup in the Tshipise-Pafuri Basin in the Limpopo Province, South Africa, records part of the infill of a passive continental margin terrain. Lithofacies analysis was performed with a view to deduce the nature of depositional environments of the Formation. Sedimentological and sequence stratigraphic evidence indicates that this unit represents a complex siliciclastic facies that reflects a fluvial paleodepositional environment. Eleven facies, which were grouped into five facies associations, were recognised. The base of the Madzaringwe Formation (Lower Member) represents a sequence deposited by braided channels. The coal deposits represent flood plain and swamp deposits, which is characterised by shale, thick coal seams, siltstone, and sandstone. The Middle Member is characterised by both clast and matrix supported conglomerates, major tubular and lenticular sandstones, and finely calcareous, micaceous siltstone. The deposition represents a sequence being formed from fluvial and particularly braided channels. The crudely stratified, coarse to pebbly sandstone indicates channel lag deposits within a heavy loaded fluvial system. The fine-grained sandstone represents deposition by shift channel and side bar deposits during lower flow conditions. The Upper Member is characterised by facies associations similar to the Lower Member, representing a new depositional cyclothem.
\end{abstract}

\section{Introduction}

The Madzaringwe Formation is a coal-bearing sequence of the late Palaeozoic Karoo Supergroup in the Tshipise-Pafuri Basin in the Limpopo Province, South Africa (Figure 1). It overlies the diamictite Tshidzi Formation. Although the Madzaringwe Formation represents one of the coal-bearing late Palaeozoic units of the Karoo Supergroup, no detailed facies analysis has been presented yet and only a few papers have dealt with paleoenvironmental aspects [1-4]. The Madzaringwe Formation is approximately $220 \mathrm{~m}$ thick and constitutes two main coal seams. The lower seam, $2.5 \mathrm{~m}$ in thickness, forms the bottom part of the composite unit directly above the diamictite [4] while the upper main seam is about $3.5 \mathrm{~m}$ thick and consists of up to nine coal bands separated by carbonaceous shale. The Mikambeni Formation is a fluvial origin [1]. Development of a more precise depositional model for this unit will provide valuable insights into basin evolution and role of syndepositional tectonism. The purpose of this study is to describe and interpret the facies and depositional environments of the poorly understood Madzaringwe Formation. Facies analysis provides much needed information on the paleoenvironments and paleogeography of this coal bearing sequence. This study provides the first relatively detailed sedimentological analysis of the unit and is based on the integration of sedimentological and sequence stratigraphic data to refine depositional models, which are usually constructed only on the basis of all sedimentological evidence. This work adds to the growing body of knowledge concerning alluvial 


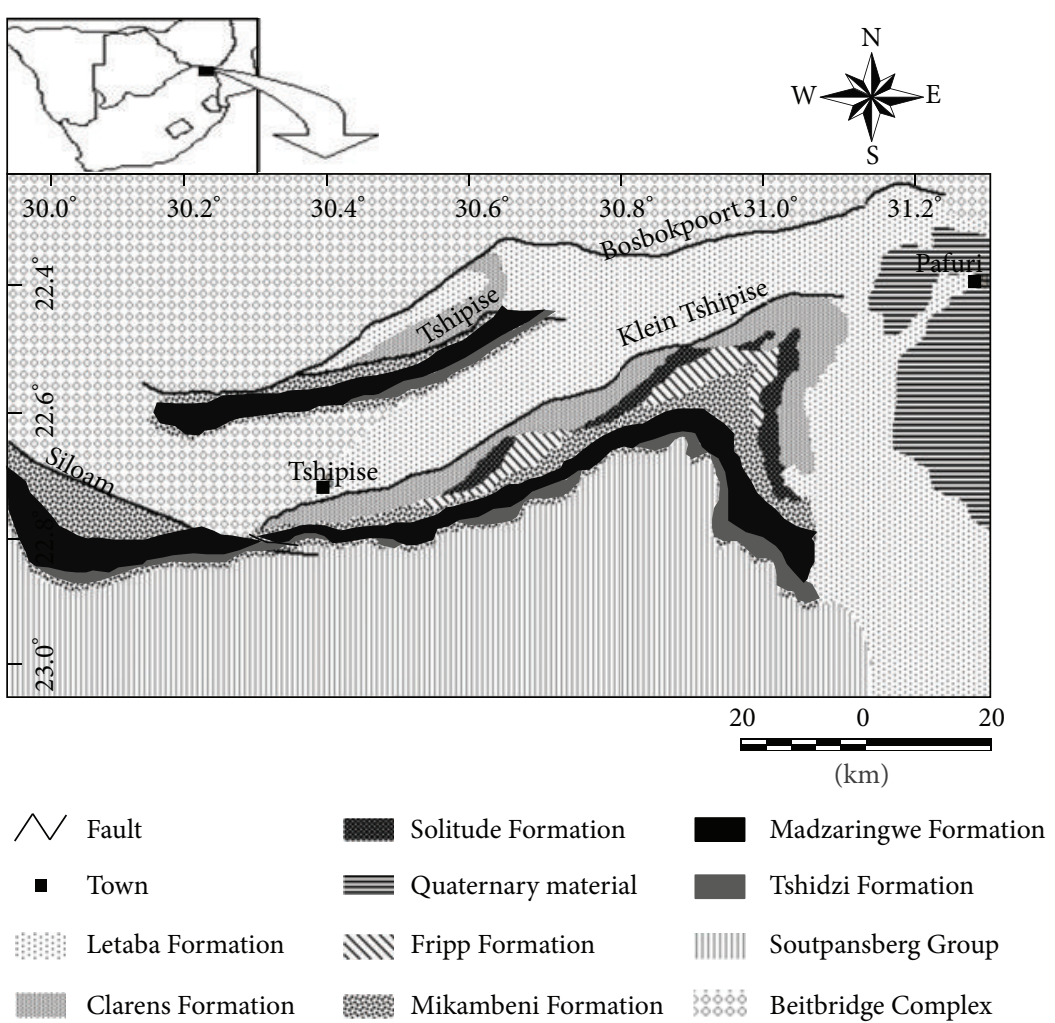

FIgURE 1: Outcrop extent of the Madzaringwe Formation within the Tshipise-Pafuri Basin, South Africa.

architecture and basin development processes in the TshipisePafuri Basin. Further, based on these analyses, a refined lithostratigraphy is established for the coal-bearing sequence.

\section{Geological Setting and Stratigraphy}

The Madzaringwe Formation comprises up to $220 \mathrm{~m}$ of alternating feldspathic, often cross-bedded conglomerates, sandstone, siltstone, and shale containing coal seams [1]. The Madzaringwe Formation overlies the diamictite Tshidzi Formation and conformably underlies the Mikambeni Formation (Figures 1 and 2). Where the Tshidzi diamictite deposits are absent, the Madzaringwe sandstones rest directly on the Soutpansberg Group quartzites. The Formation in this basin is developed in a more or less NE-SW elongated faultbounded half graben, intracratonic basin. The sandstone is feldspathic, micaceous, and commonly cross-bedded. The basal 35 to $40 \mathrm{~m}$ of the Formation comprises feldspathic, micaceous fine to medium grained sandstone, carbonaceous shale, and thin coal seams. The lower seam, $2.5 \mathrm{~m}$ in thickness, forms the bottom part of the composite unit above the diamictite [4]. The main coal seam is 2 to $3 \mathrm{~m}$ thick and consists of nine coal bands, separated by carbonaceous shale. The Formation reflects a fluvial depositional system. It appears to have been laid down by meandering rivers flowing from the northwest. The sandstone probably represents point bar, levee and crevasse splay deposits. Plant material accumulated in flood basins under cool, reducing conditions, giving rise to the formation of coal seams.

\section{Previous Work}

The Madzaringwe Formation was originally named by Brandl and McCourt [3], but only basic lithological and faunal information of the Formation was provided. They suggested a Permian age but did not record the thickness of the Formation or designate a type section. Brandl $[1,2]$ carried out the first detailed work on the Formation, studied the sedimentology, and measured a stratigraphic succession of the Formation. Brandl $[1,2]$, Brandl and McCourt [3] suggested that the Madzaringwe Formation was formed by fluvial systems.

\section{Methodology}

The sedimentology of the Madzaringwe Formation was analysed in detail at a number of localities among the TshipisePafuri Basin (Figure 1). Detailed review of the spatial stratigraphic variation of the successions, including the analysis of facies changes based on over 500 widely distributed borehole records, field observations, and paleocurrent measurements was performed. The above mentioned set of borehole data resulted from the extensive coal exploration activities in the study area by different companies over the past 50 years. Many units were walked out in order to characterise their regional extent and architecture. Detailed facies and architectural analyses were performed, with particular attention devoted to channel morphology and vertical stacking patterns. Characterisation of bedding hierarchy was carried out by using the classification scheme of Miall [5]. Paleocurrents 


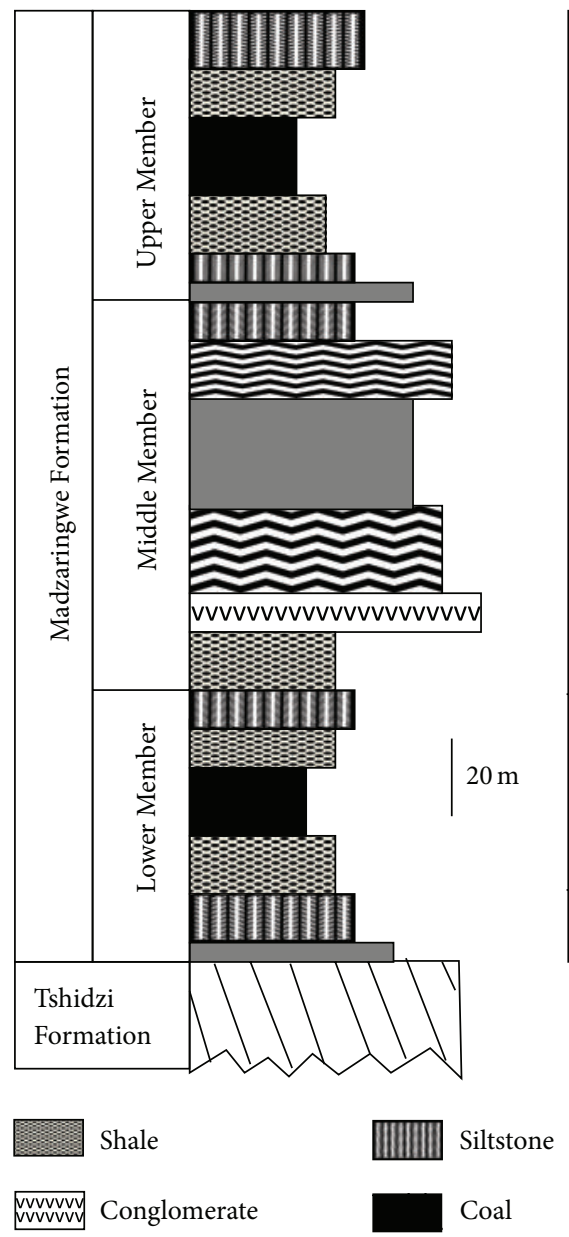

\begin{tabular}{|l|l|}
\hline Cross-laminated siltstones & Abandoned channel and floodplain \\
\hline Carbonaceous and laminated shale & Floodplains and backswamps \\
\hline Coal, shaly coal & Densely vegetated backswamps \\
\hline Carbonaceous and laminated shale & Floodplains and backswamps \\
\hline $\begin{array}{l}\text { Cross-laminated siltstones/medium } \\
\text { grained sandstone }\end{array}$ & $\begin{array}{l}\text { Vertical accretion on the top of } \\
\text { channel sand bars }\end{array}$ \\
\hline Coarse to pebbly sandstone & Channel lag deposits \\
\hline $\begin{array}{l}\text { Fine-medium } \\
\text { grained sandstone }\end{array}$ & Channel-like deposits \\
\hline $\begin{array}{l}\text { Coarseto pebbly sandstone } \\
\text { Clast and matrix supported conglomerates }\end{array}$ & Channel lag deposits \\
\hline Carbonaceous and laminated shale & Floodplains and backswamps \\
\hline $\begin{array}{l}\text { Carbonaceous and laminated shale } \\
\text { with siltstone }\end{array}$ & Floodplains \\
\hline Coal, shaly coal & Densely vegetated backswamps \\
\hline Carbonaceous and laminated shale & Floodplains and backswamps \\
\hline $\begin{array}{l}\text { Cross-laminated siltstones and } \\
\text { sandstone }\end{array}$ & Floodplains and channel lag \\
\hline
\end{tabular}

Coarse grained sandstone

Fine-medium grained sandstone

Figure 2: Stratigraphic succession displaying facies succession, depositional environments, and sequence stratigraphy of the Madzaringwe Formation in the Tshipise-Pafuri Basin.

were derived from planer and trough cross-beddings and asymmetric ripple cross-laminations.

\section{Sedimentary Facies and Facies Associations}

Facies analysis of the Madzaringwe Formation was carried out using a modified version of Miall's $[6,7]$ lithofacies classification scheme. Based on the identification of 11 lithofacies (Table 1), their internal and external geometry, and their relationship in the Madzaringwe Formation, these facies can be integrated into five distinct facies associations (FA). The characteristics of these facies and facies associations are shown in the Tables 1 and 2.

\subsection{Conglomerate Facies (FA 1)}

5.1.1. Description. FA 1 is characterised by conglomerate ( $\mathrm{Gcm}$, and occasionally $\mathrm{Gmm}$ ) with thicknesses from $<0.1$ to $3 \mathrm{~m}$ and subordinate sandstone lithofacies Se and St (Tables 1 and 2; Figures 3 and 4). The conglomerates are reddishgreyish in colour and consist of granule to pebbly sized grains, with well-rounded concretions. The clasts are composed of red to brownish grey, subangular to subrounded sandstone and siltstone; white, brownish to reddish, subangular to subrounded mudstone and reddish to whitish, subrounded to rounded quartz pebbles. The rounded cobbles and pebbles can measure from 1 to $30 \mathrm{~cm}$ in diameter (Figure 3(b)). The matrix is red to greyish brown siltstone, occasionally with coarse, rounded reddish quartz grains. FA 1 commonly occurs at or near the bases of major tabular/lenticular sandstones (FAs 2 and 3). The conglomerates are invariably topped by, or interbedded with, sandstone units (Se and Sr; Figure 3(a)). Using the field observations and borehole data, the thickness of this association can be estimated to be $>100 \mathrm{~m}$ in some places.

5.1.2. Interpretation. The conglomerates are polymictic, texturally immature and crudely stratified or massive (Figure 3). The clast-supported massive conglomerate units were deposited most probably as small bodies of channel lag or longitudinal braided bars of low sinuous streams. The occasionally matrix-supported and poorly sorted conglomerate unit might have been deposited as debris flow deposits. These conglomerates might have resulted from fluvial fan accumulation in response to uplift along faulted margin [8]. 
TABLE 1: Lithofacies identified in the Madzaringwe Formation.

\begin{tabular}{|c|c|c|c|}
\hline $\begin{array}{l}\text { Coarse grained } \\
\text { lithofacies }\end{array}$ & Description & $\begin{array}{l}\text { Fine grained } \\
\text { lithofacies }\end{array}$ & Description \\
\hline $\mathrm{Gcm}$ & $\begin{array}{l}\text { Clast-supported conglomerate. Colour: light } \\
\text { brownish to red. Matrix: mostly absent; } \\
\text { fine-medium sand if present } \\
\text { Clasts: typically granule to pebbly sized, up } \\
\text { to boulder size; poorly sorted; subangular to } \\
\text { rounded }\end{array}$ & Sf & $\begin{array}{l}\text { Massive to slightly laminated muddy } \\
\text { sandstones } \\
\text { Colour: light grey, grey to khaki. Grain size: } \\
\text { very fine to coarse grained sand, poorly } \\
\text { sorted }\end{array}$ \\
\hline $\mathrm{Gmm}$ & $\begin{array}{l}\text { Matrix-supported conglomerate. Colour: } \\
\text { light brownish grey, reddish grey } \\
\text { Matrix: clay to sand; typically massive, } \\
\text { occasionally laminated. Clasts: typically } \\
\text { granule to pebbly sized; up to boulder size; } \\
\text { poorly sorted; subangular to subrounded }\end{array}$ & $\mathrm{Fl}$ & $\begin{array}{l}\text { Laminated siltstone and fine sandstone, with } \\
\text { very small ripples. Colour: Khaki grey to } \\
\text { khaki }\end{array}$ \\
\hline $\mathrm{Se}$ & $\begin{array}{l}\text { Crudely stratified to massive sandstone. } \\
\text { Color: light gray } \\
\text { Grain size: coarse to very coarse sand }\end{array}$ & $\mathrm{Fc}$ & $\begin{array}{l}\text { Massive to laminated carbonaceous } \\
\text { mudstone/shale. Abundant to rare } \\
\text { carbonized plant material. Colour: grey to } \\
\text { dark grey }\end{array}$ \\
\hline St & $\begin{array}{l}\text { Trough cross-bedded sandstone. Colour: } \\
\text { reddish brown, khaki to grey. Grain size: } \\
\text { medium to coarse grained sand. Thickness is } \\
0.1-2.0 \mathrm{~m}\end{array}$ & Fsm & $\begin{array}{l}\text { Silt and mudstone. Colour: black. Occurring } \\
\text { in backswamps }\end{array}$ \\
\hline Sh & $\begin{array}{l}\text { Horizontally stratified sandstone. Colour: } \\
\text { light Grey, khaki to reddish brown. Grain } \\
\text { size: very fine to medium grained sand }\end{array}$ & $\mathrm{Fm}$ & $\begin{array}{l}\text { Mudstone and silt. Colour: black. Occurring } \\
\text { in overbank and or drape deposits }\end{array}$ \\
\hline $\mathrm{Sp}$ & $\begin{array}{l}\text { Sand, very fine to medium } \\
\text { Colour: reddish brown, khaki to grey. Grain } \\
\text { size: very fine to medium grained sand }\end{array}$ & $\mathrm{C}$ & $\begin{array}{l}\text { Coal stringers, } 1-7 \mathrm{~cm} \text { thick; }<2-3 \mathrm{~m} \text { long. } \\
\text { Colour: black. Occurring within mudstone, } \\
\text { or black shale }\end{array}$ \\
\hline $\mathrm{Sr}$ & $\begin{array}{l}\text { Sand, very fine to fine grained with ripples. } \\
\text { Cross-laminated } \\
\text { Colour: reddish brown, khaki to grey. Grain } \\
\text { size: very fine to fine grained sand }\end{array}$ & & \\
\hline $\mathrm{Sm}$ & $\begin{array}{l}\text { Sand, very fine to coarse. Massive or faint } \\
\text { lamination. Colour: reddish brown, khaki to } \\
\text { grey. Grain size: very fine to medium } \\
\text { grained sand }\end{array}$ & & \\
\hline S1 & $\begin{array}{l}\text { Sand, medium to coarse, may be pebbly. } \\
\text { Colour: light grey, grey to khaki. Grain size: } \\
\text { medium to very coarse sand }\end{array}$ & & \\
\hline
\end{tabular}

TABLE 2: Facies associations identified in the Madzaringwe Formation.

\begin{tabular}{lccl}
\hline Facies associations & & Facies & Interpretation of depositional environments \\
\hline $\begin{array}{l}\text { Conglomerate } \\
\begin{array}{l}\text { Major tabular and lenticular } \\
\text { sandstone }\end{array}\end{array}$ & FA 1 & Gcm, Gmm, Se, St 2 & $\begin{array}{l}\text { Dominantly alluvial and braided fluvial } \\
\text { channels }\end{array}$ \\
$\begin{array}{l}\text { Fine laminated calcareous siltstone } \\
\text { Sandy shale/mudstone }\end{array}$ & FA 3 & FI, Fr, Sh, Sp, Sm, SI & Dominant braided channels, channels \\
Carbonaceous shale/mudstone & FA 4 & FI, Sh, St, C & $\begin{array}{l}\text { Shallow lake, flood plain. } \\
\text { Floodplain plain, lake and weakly developed } \\
\text { palaeosol }\end{array}$ \\
\hline
\end{tabular}

\subsection{Major Tabular and Lenticular Sandstone (FA 2)}

5.2.1. Description. The major tabular and lenticular sandstone FA 2 is more common in the Madzaringwe Formation. They are composed of the following lithofacies, in descending order of abundance: Sm, St, Sp, Sh, Sl, and Sr, (Tables 1 and 2; Figures 5 and 6). FA 2 occurs as single and multilayered units, which commonly exceed hundreds of meters in lateral extent. Tabular sandstone bodies are characterised by a width/thickness ratio exceeding 15 , whereas lenticular 


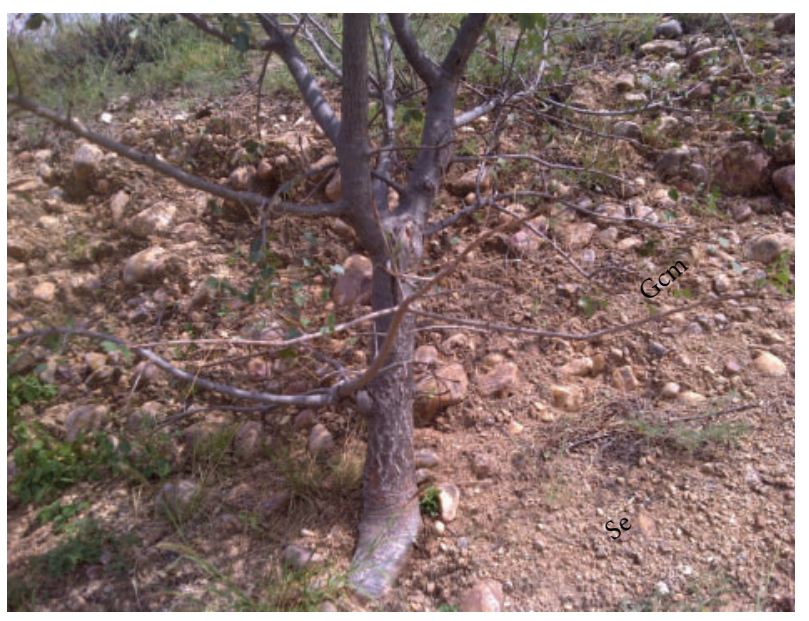

(a)

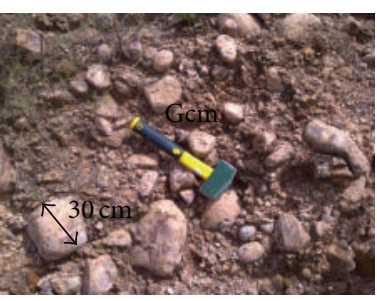

(b)

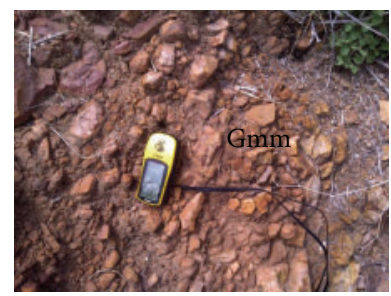

(c)

Figure 3: (a) Clast-supported conglomerate with very coarse sandstone. (b) Rounded cobbles and pebbles measuring from $1 \mathrm{~cm}$ to $35 \mathrm{~cm}$ in length. (c) Clast-supported conglomerate (angular to subangular pebbles measuring $1 \mathrm{~cm}$ to $10 \mathrm{~cm}$ in length).

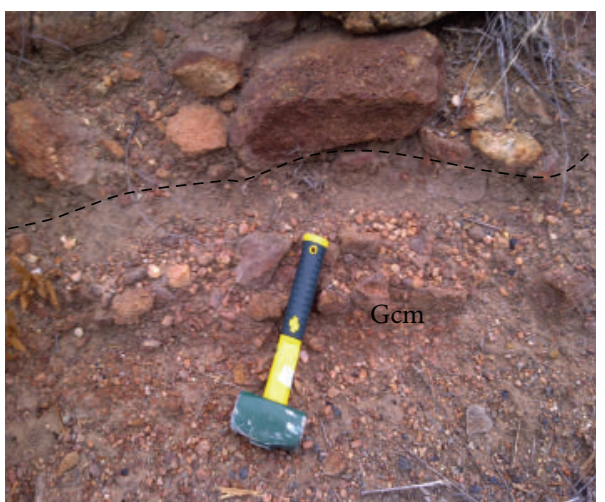

(a)

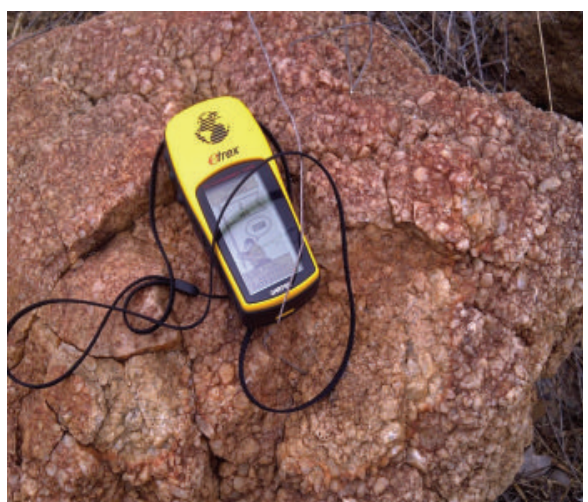

(b)

FIGURE 4: Clast-supported conglomerate.

sandstone bodies are <15. FA 2 beds exhibit the following internal bedding features:

(i) massive reddish brown, khaki to grey sandstone beds $(\mathrm{Sm})$. The grain size is very fine to coarse with massive or faint lamination.

(ii) Trough cross-bedding reddish brown, khaki to grey sandstone (St). The grain size is fine to coarse with thicknesses ranging from 0.1 to $2.0 \mathrm{~m}$.

(iii) Horizontal light grey, khaki to reddish brown laminated sandstone (Sh). The grain size is very fine to medium grained sand.

(iv) Low angle cross-bedding sandstone, medium to coarse and may be pebbly with a light grey, grey to khaki colour (S1).

(v) Reddish brown, khaki to grey planar cross-bedded sandstone with very fine to medium grained sand (Sp). (vi) Reddish brown to khaki grey ripple cross-laminated sandstone $(\mathrm{Sr})$. The grain size is very fine to medium grained.

Most sandstones in FA 2 are subangular to rounded, moderately to poorly sorted, composed of quartz, feldspar, mica, lithics (rock fragments) and minor dark heavy minerals. The matrix/cement materials are argillaceous, carbonaceous, and at places ferruginous. Coarse to pebbly sandstone is poorly developed sublithofacies that generally overlies the conglomerate and grades vertically into coarse to medium sandstones. The sublithofacies commonly occur as multistoreyed channel-like sandstone bodies. Thin strata of mudstone and siltstone separate the successive sandstone bodies (Figure 5). Coarse grained sandstone sublithofacies occurs as 2 to $5 \mathrm{~m}$ thick individual channels to sheet-like sandstone bodies that are massive or trough and planar cross-stratified (Figure 6(b)). Medium-grained sandstone sublithofacies varies from 2 to $3.5 \mathrm{~m}$ in thickness (Figures 6(a), 6(b), 6(c), and 6(d)). This sublithofacies occurs as sandstone bodies with erosional or transitional base and a flat top. It constitutes multistoreyed 


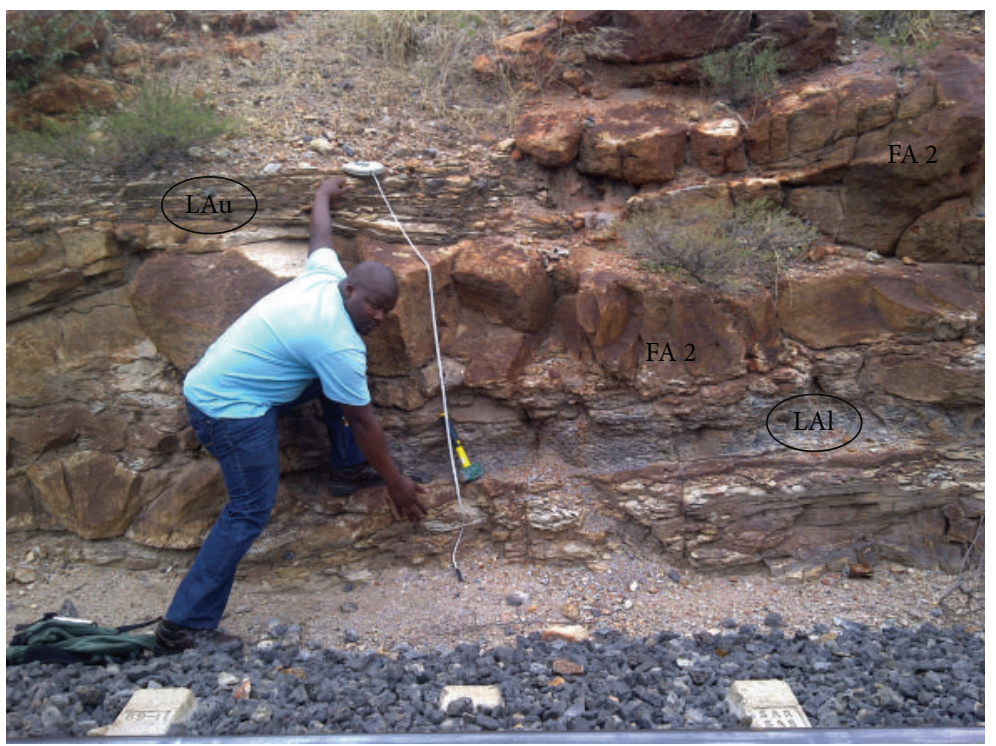

(a)

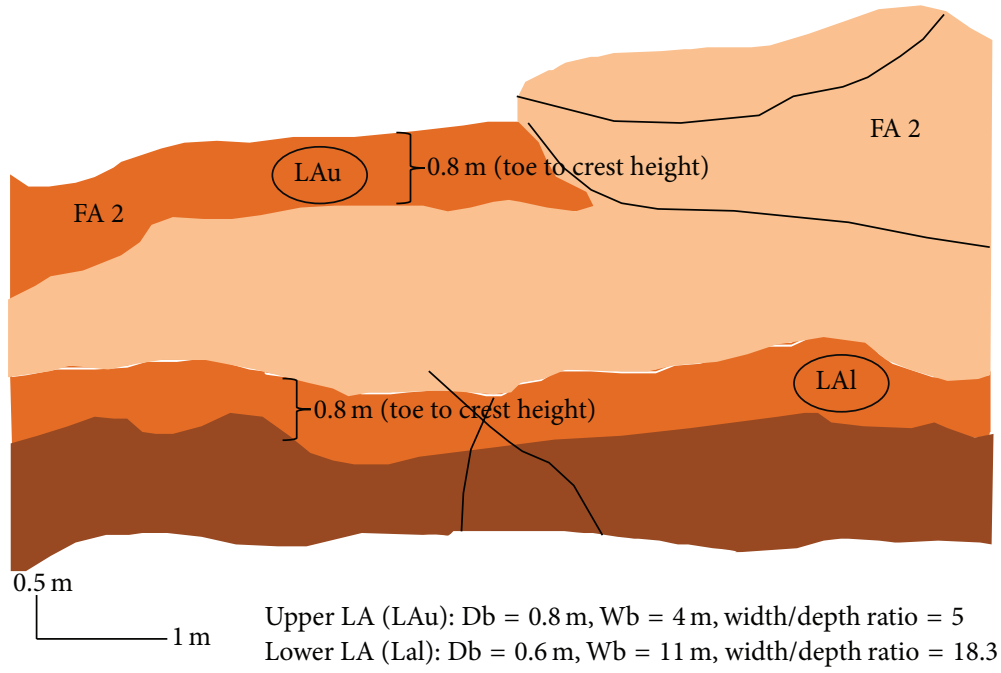

(b)

FIGURE 5: Major tabular sandstones (FA 2) exhibiting fine-grained, point-bar lateral accretion sets (LA), which are used to estimate paleochannel dimensions; (a) photomosaic of FA 2; (b) interpretation of photomosaic in (a). LAu is the Upper Lateral Accretion; LAl is the Lower Lateral Accretion; $\mathrm{Db}$ is the depth and $\mathrm{Wb}$ is the width.

sandstone bodies with abundant successive sets of large-scale trough, planar, and parallel or ripple stratifications. Finegrained sandstone sublithofacies comprises interbedded siltstone and mudstone. Individual bodies vary from 1 to $4 \mathrm{~m}$ in thickness.

The outcrops of the major tubular sandstone facies assemblage have lateral extents of less than a few meters to more than one hundred meters. Sedimentary structures include thin $(3-10 \mathrm{~cm})$ to medium $(10-30 \mathrm{~cm})$ beds of trough and planar sandstone cross-laminae. Major lenticular sandstones share many of the same characteristics as tubular sandstone, including minimum thickness, most lithofacies (Gcm, St, Gmm, Se, and Sr), composition, colour, and grain size.
5.2.2. Interpretation. Major tabular and lenticular sandstones are interpreted as fluvial channel deposits based upon their dimensions, facies distribution, and sedimentary structures. The crudely stratified, coarse to pebbly sandstone indicates channel lag deposits within a heavy loaded fluvial system. The coarse to medium and locally fine-grained sandstone bodies with erosional bases and flat top form channel-like deposits. Fine-grained sandstone represents deposition by vertical accretion on the top of channel sand bars during lower flow conditions [9]. Abundant large-scale trough and planar crossstratified cosets in multistoreyed sandstone sequence may be attributed to downcurrent migration of sand dunes, sand waves, and transverse bars in shallow water stream channels [10]. In the Soutpansberg area point-bar lateral accretions 


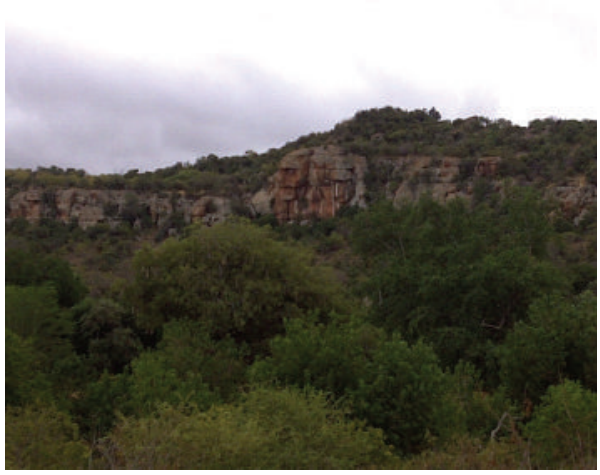

(a)

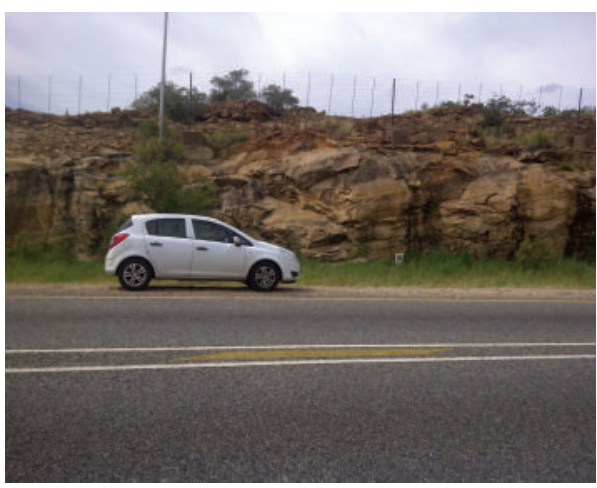

(c)

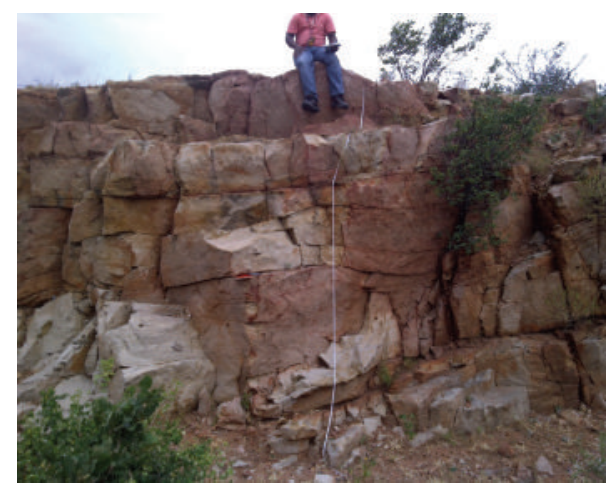

(b)

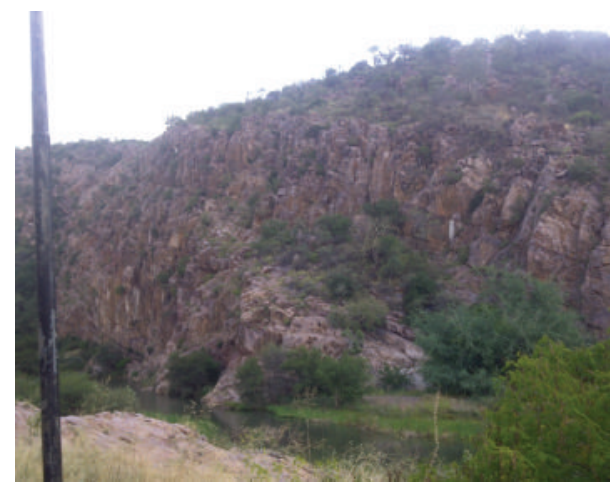

(d)

FIGURE 6: Massive reddish brown, khaki to grey sandstone beds (Sm).

beds are common (Figure 5). The fine grain size (generally fine sandstone) and point bar elements are consistent with meandering-style rivers (Miall, 1990).

\subsection{Finely Calcareous and Micaceous Siltstone (FA 3)}

5.3.1. Description. FA 3 is composed of bimodal, well-sorted, and medium grained, light grey siltstone and silty-very finegrained sandstone (Figures 7(a), 7(b), and 7(c)). It generally occurs as either individual strata or alternated with very fine-grained sandstones and shales in the upper part of the individual depositional units. Individual siltstone strata are about 0.3 to $3 \mathrm{~m}$ and even less than a centimetre thick having both sharp and gradational contacts. The siltstones are dirty white, grey to black, and pinkish in colour with argillaceous or carbonaceous matrix and show parallel and cross-lamination. The lithofacies tends to coarsen upward and the thickness ranges from 0.3 to $3 \mathrm{~m}$. Based on core observations, the facies is regionally correlative in the Mikambeni Formation of all the coalfields. Common diagenetic features are rich of calcite concretions (Figure 7(c)). FA 3 is interpreted to reflect deposition by shallow lakes and ponds in a flood plain environment.

5.3.2. Interpretation. The parallel and cross-laminated siltstones were probably deposited on the top of sand bars and closely linked with abandoned channel and floodplain conditions during the periods of reduced hydrodynamic energy and sediment discharge by vertical accretion or slow deposition [11]. Thin and lenticular siltstone at bar top sequence suggests its deposition from suspension during falling stage of water flow and due to rapid shifting of channel bars. Thick and persistent siltstone is associated with floodplain sequence which is attributed to deposition through extensive and long persistent overflow of stream. Siltstones with carbonaceous materials indicate that the flood plain was flanked by vegetated overbank. The presence of load casts and other soft deformation structures in the sediments indicate rapid deposition and water-saturated condition [11].

\subsection{Sandy Shale/Mudstone (FA 4)}

5.4.1. Description. It is the most dominant FA in the Madzaringwe Formation. FA 4 is characterised by lithofacies $\mathrm{Fm}, \mathrm{Fl}$, with minor St, Sh, and C (Tables 1 and 2; Figure 8). The lithofacies is commonly present in association with coal, carbonaceous siltstone and fine-grained sandstone (Figure 8). Individual bed ranges between 0.3 and $100 \mathrm{~m}$ thick persist laterally for 10 to $100 \mathrm{~s}$ of meters. FA 4 mainly consists of massive to parallel laminated $(\mathrm{Fm}, \mathrm{Fl})$ and contains interbedded dark grey, reddish brown or carbonaceous mudstones and light grey, silty sandstone. Shale facies can be described as having three variations: ferruginous shale, pyritic shale, and micaceous shale. The top and bottom contacts of the lithofacies are sharp and gradational. It mainly overlies the sandstone and siltstone lithofacies. These variations are equivalent to 


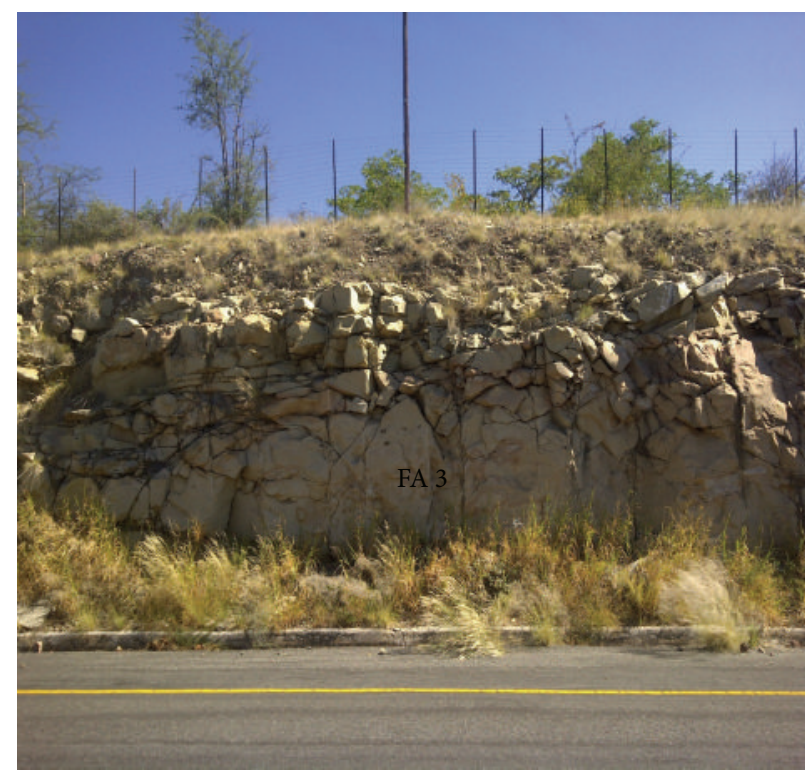

(a)

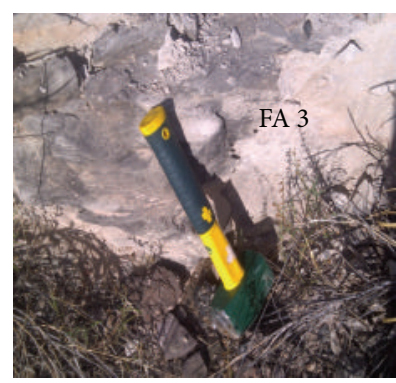

(b)

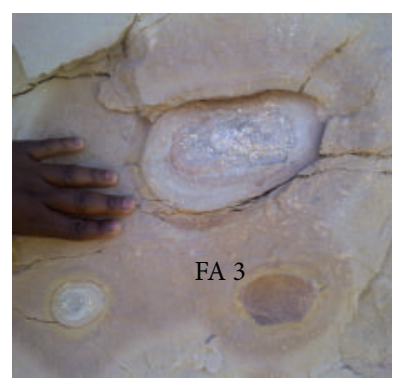

(c)

Figure 7: (a) Massive siltstone. (b) Thin laminated siltstone and (c) calcite concretions in siltstone.

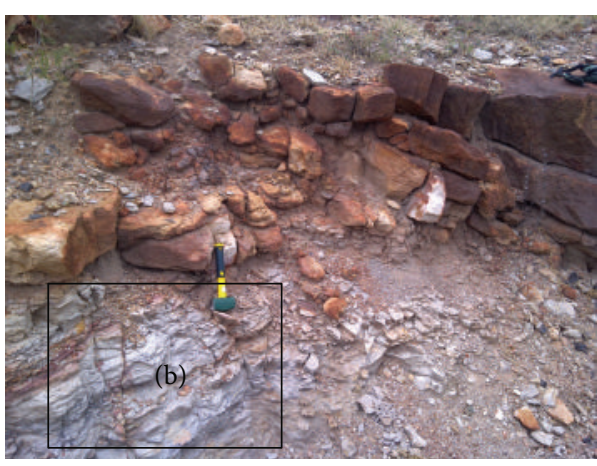

(a)

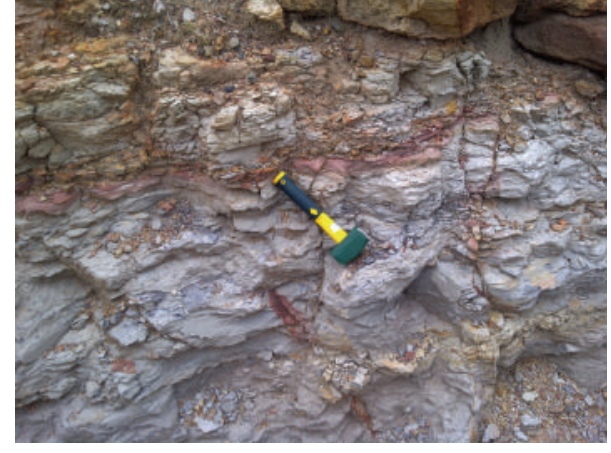

(b)

Figure 8: ((a) and (b)) FA 5 shale overlain by sandstone (FA 3) in the Madzaringwe Formation.

Bordy and Catuneanu's [12] "Sedimentological study of the Fluvial Tuli Basin" facies in the Tuli Coalfield and Brandl's [2] "Geology of the Alldays Area" in the Soutpansberg Coalfield.

5.4.2. Interpretation. Parallel laminated shale suggests that the sediments were deposited in floodplain environments with frequent variation of energy condition, thus resulting in grain-size variation vertically or laterally. Thin mudstone at top of the channel sandstones indicates deposition from suspension during channel abandonment. The thick dark mudstone associated with coal suggests deposition by vertical accretion in backswamp or flood basin environments [11, 13]. Bands of sandstone and siltstone within the facies association were introduced during periodic events of floods. The presence of carbonaceous mudstone indicates a moderate growth of vegetation in and around the basin.

\subsection{Carbonaceous Shale and Coal (FA 5)}

5.5.1. Description. Three coal zones are identified within the borehole depth (named the basal, middle, and upper coal zones). FA 5 is characterised by lithofacies Fc and C (Tables 1 and 2; Figure 9). Lithofacies Fc is commonly interlayered with C. It is generally overlain by FA 4 and consists of true coal (high volatile $\mathrm{C}$ to A bituminous), shaly coal, carbonaceous shale to carbonaceous siltstone. The thicknesses range from a few centimetres to a couple meters (common $3 \mathrm{~m}$ ). In this study shaly coal is referred to coal interlayered with thin bands of carbonaceous shale and shale. The lithofacies commonly overlies the alternated sequences of sandstone, siltstone, and mudstone. The coal is dull black to shiny black in colour and vitreous to subvitreous in lustre. The coal is classified as subbituminous to bituminous. At places, the coal may grade into shaly coal to carbonaceous shale. Interseam 


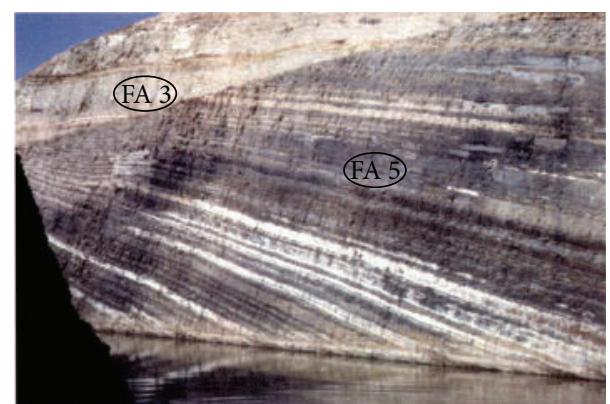

FIGURE 9: FA 5, alternating carbonaceous shale and coal seams in the Madzaringwe Formation at Mopane Coalfield overlain by siltstone layers (FA 3).

partings of sandstone and mudstone are also commonly present.

5.5.2. Interpretation. FA 5 is interpreted to represent flood basin pond and back swamp deposits based on the abundance of preserved organic materials. Carbonaceous shale is commonly observed as part of a facies progression capping many floodplain pond successions. Due to their high carbon content, common drab and dark gray colours and carbonaceous shales are interpreted to have occurred within a well-vegetated and wet paleoenvironment. It is most probably linked with the lower reaches of a fluvial stream system.

The thick coal seam indicates a long persistent, slowly subsiding, moderately drained, and densely vegetated backswamp [14]. The thin coal seams contain abundant splits of carbonaceous mudstone that indicates a short-lived flooding during that period. The thick coal seams are thought to result from the combined interaction of various factors, like localised aggradation of channels, slow and steady subsidence of the basin area, abundant rainfall to grow luxuriant vegetation, abundant supply of paleoflora, comparatively higher water table, and long period of stable time [13].

\section{Vertical Sequence and Coal Seam Development}

Three identified informal members (lower, middle, and upper) of the Madzaringwe Formation are recognisable. They resemble characteristics of various fluvial depositional environments. The laminated, grey and black carbonaceous shale and coal of FA $5(\mathrm{Fc}, \mathrm{C})$ and sandy shale/mudstone of FA 4 (F1, Sh, St, and C) form the Lower Member which rests on pre-Karoo rocks or Tshidzi Formation. They display laminated, pyritic, micaceous, and sometimes ferruginous characteristics of a quiet, low energy setting, dominated by slow suspension settling. Coal and carbonaceous shale (FA 5) were probably deposited in well drained swamps whereas peat in poorly drained swamps. Parallel laminated shale (FA 4) suggests that the sediments were deposited in floodplain environments with frequent variation of current energy condition. Thin mudstone at the top of the channel sandstones indicates deposition from suspension during channel abandonment. The thick dark mudstone associated with coal seams suggests deposition by vertical accretion in backswamp or flood basin environments.

The Middle Member is characterised by alternating beds of shale and fine-coarse grained sandstone to siltstone (FA 1, FA 2, and FA 3). FA 1 ( $\mathrm{Gcm}, \mathrm{Se}$, and $\mathrm{St}$ ) environments display dominant fluvial braided channels and crevasse splays. FA 2 (St, Sr, and Sh) depositional environments are associated with dominant fluvial channels, crevasse splays, levees and crevasse channels. FA 3 (F1, Sr, and St) depositional environments are associated with shallow lakes in a flood plain setting.

The Upper Member is characterised by facies similar to the Lower Member, laminated, grey and black carbonaceous shale and coal of FA $5(\mathrm{Fc}, \mathrm{C})$ and sandy shale/mudstone of FA 4 (F1, Sh, St, and C). The coal seams and carbonaceous shale (FA 5) were deposited in swamps. The sandy shale/mudstone (FA 4) was probably deposited in floodplain ponds, lakes, and weakly developed paleosols.

\section{Depositional Environments and Paleogeography}

Detailed analysis of lithofacies types and facies assemblages in the Madzaringwe Formation suggests fluvial paleochannel depositional environments. The facies associations identified in the formation resemble those of a fluvial depositional environments dominated by streams, lakes, swamps, and ponds. Three identified informal members (Lower, Middle, and Upper) of the Madzaringwe Formation resemble characteristics of the Facies associations (FA 1, 2, 3, 4, and 5) in a prograding fluvial depositional environment. The laminated, grey and black carbonaceous shale and coal of FA 5 (Fc, C) and sandy shale/mudstone of FA 4 (F1, Sh, St, and C) form the Lower Member of the sequence. The Middle Member is characterised by alternating beds of shale and fine-coarse grained sandstone to siltstone, FA 1 (Se and St), FA 2 (St, Sr, and Sh), and FA 3 (F1, Sr, and St). Succeeding the Middle Member is the Upper Member which has almost the same depositional environments as those of the Lower Member. It is characterised by grey and black carbonaceous shale and coal of FA 5 (Fc, C) and sandy shale/mudstone of FA 4 (F1, Sh, St, and C).

In the present study, a conceptual model has been constructed to provide an idea about the paleogeography and environments of deposition of the Madzaringwe Formation of the Tshipise-Pafuri Basin (Figure 10). Internal sedimentary structures, boundary conditions, lithofacies, their interrelationships, vertical sequence, and facies association are taken into consideration for the interpretation of depositional environments. This Formation is overlain by another cycle of a thick conglomerate and alternated sequence of conglomerates and trough to planar cross-stratified sandstones and siltstones, alternating shale, shaly coal, and carbonaceous shale.

All these suggest deposition under channelized condition in moderately sinuous stream in an alluvial fan to fluvial plain setting (Figure 10(a)). Consequently, the gradient of the stream is reduced to form comparatively fine-grained and small-scale sequences with several horizons of thin coal seams. The peat-forming swamps were very short lived and most probably were moderate to well drained, which is 

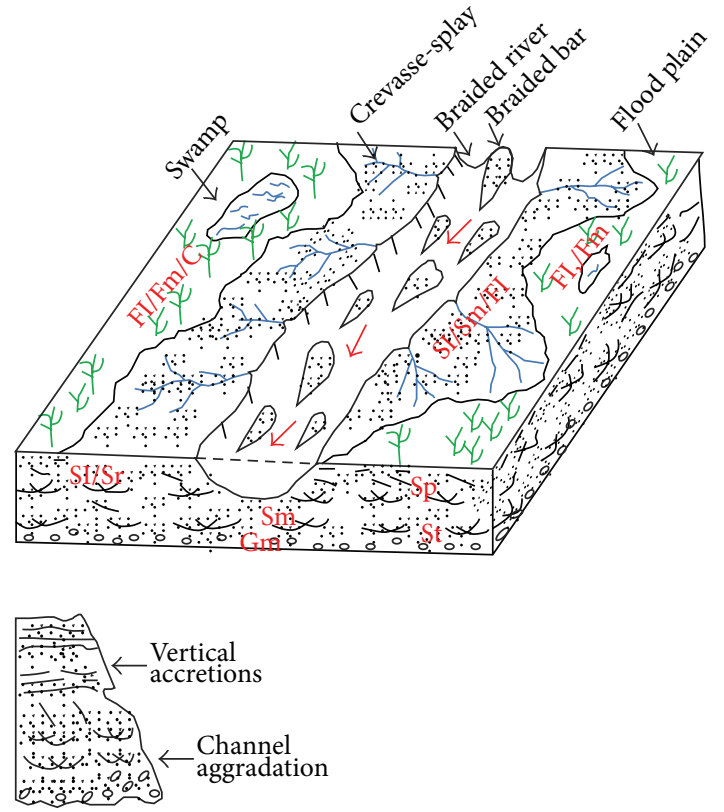

(a)
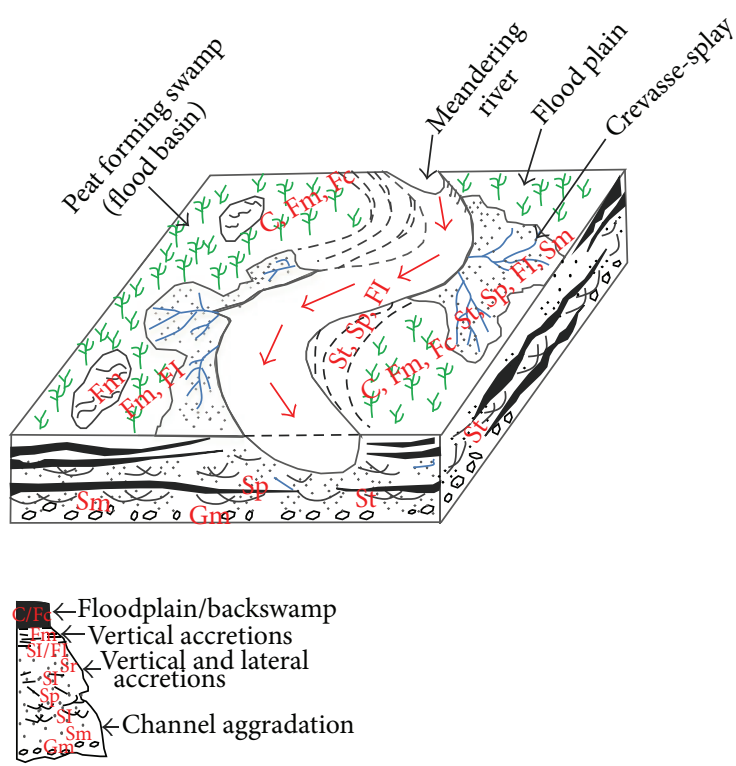

(b)

FIGURE 10: Schematic block diagrams with sedimentary sequence showing the environments of deposition ((a) and (b)) in the Madzaringwe Formation of the Tshipise-Pafuri Basin.

indicated by the presence of repeated sequence of coarse to fine clastics with intervening thin coal seams. Gradually, this situation changed to more peneplain condition to deposit thick coal materials (seams) in a long moderately drained to poorly drained and densely vegetated peat-forming backswamps along with sinuous streams. The mudstone/shale and siltstone were deposited in natural levee or flood basin. But the occurrence of carbonaceous mudstone indicates more stagnant condition in backswamp and abandoned channel conditions with sparse vegetation (Figure 10(b)).

The sedimentary facies, sequence, and their vertical changes in facies association indicate a progressive decrease in coarse clastics and an increase in fine clastics and coal upward. The evidence for this comes from the fining-upward channel-fill sequences which were built up by numerous flooding events as indicated by the desiccated mud drapes and internal erosion surfaces [15]. This in turn suggests a progressive decline of stream gradient and current energy competency from bottom to top of the sequence. The lithofacies of the succession of this basin form several repeated fining upward sequences and minor coarsening upward subsequences.

\section{Conclusions}

Relatively detailed facies and facies architectural analysis of Madzaringwe Formation was performed for the first time, enhancing the understanding of the depositional history, paleogeography, and controlling factors on the deposition of this thick, coal rich sequence. The Madzaringwe Formation is interpreted to occur in a clastic fluvial depositional environment. A total of fifteen lithofacies were identified in this
Formation, which resulted in recognition of five distinct facies associations (FAs): conglomerate (FA 1); major tabular and lenticular sandstone (FA 2); fine calcareous and micaceous siltstone (FA 3); sandy shale/mudstone (FA 4); and carbonaceous shale and coal (FA 5). There are three informal members (Lower, Middle, and Upper) recognisable in the Madzaringwe Formation. FA 5 (Fc, C) and sandy shale/mudstone of FA 4 (F1, Sh, St, and C) form the Lower Member of the Formation. The Middle Member is characterised by FA 1 (Se and St), FA 2 (St, Sr, and Sh), and FA 3 ( $\mathrm{F} 1, \mathrm{Sr}$, and St). Succeeding the Middle Member is the Upper Member which is represented by FA 4 and FA 5.

\section{Acknowledgments}

This paper is from Ntokozo Malaza's Ph.D. research project that was financially sponsored by the Coaltech Research Association, and special thanks are extended to its executive director, Mr. Johann Beukes. Dr. G. Brandl is thanked for his technical and field support. S. Mbatyoti and T. B. Nephawe are thanked for their help during the field work. The Department of Geology, University of Fort Hare, is thanked for logistic support.

\section{References}

[1] G. Brandl, "The geology of the Messina area," Tech. Rep. Explanation sheet 2230, Geological Survey of South Africa, Messina, Italy, 1981.

[2] G. Brandl, "The geology of the Alldays area," Tech. Rep. Explanation sheet 2228, Geological Survey South Africa, Alldays, South Africa, 2002. 
[3] G. Brandl and S. McCourt, "A lithostratigraphic subdivision of the Karoo Sequence in the north-eastern Transvaal," Annals Geological Survey of South Africa, vol. 14, pp. 51-56, 1980.

[4] J. H. Sullivan, The geology of the coal-bearing rocks of the Karoo Sequence in the Tshikondeni mine area, northern Transvaal [M.S. thesis], University of Pretoria, 1995.

[5] A. D. Miall, "Architectural elements and bounding surfaces in fluvial deposits: anatomy of the Kayenta formation (lower jurassic), Southwest Colorado," Sedimentary Geology, vol. 55, no. 3-4, pp. 233-262, 1988.

[6] A. D. Miall, "Lithofacies types and vertical profile models in braided river deposits: a summary," in Fluvial Sedimentology, A. D. Miall, Ed., vol. 5, pp. 597-604, Canadian Society of Petroleum Geologists Memoir, 1978.

[7] A. D. Miall, The Geology of Fluvial Deposits: Sedimentary Facies, Basin Analysis and Petroleum Geology, Springer, New York, NY, USA, 1996.

[8] A. D. Miall, "Alluvial sedimentary basins. Tectonic setting and basin architecture," in Sedimentation and Tectonics in Alluvial Basins, A. D. Midall, Ed., vol. 23, pp. 1-33, Geological Association of Canada, 1981.

[9] I. C. Rust, "Tectonic and sedimentary framework of Gondwana basins in southern Africa," in Gondwana Geology, K. S. W. Campbell, Ed., pp. 537-564, Australian National University Press, Canberra, Australia, 1975.

[10] A. D. Miall, "Alluvial deposits," in Facies Models: Response to Sea-Level Change, R. G. Walker and N. P. James, Eds., pp. 119142, Geological Association, Canada, 1992.

[11] R. G. Walker and D. J. Cant, "Sandy fluvial systems," in Facies Models, R. G. Walker, Ed., Reprint Series 1, pp. 71-89, Geoscience, Canada, 2nd edition, 1984.

[12] E. M. Bordy and O. Catuneanu, "Sedimentology of the lower Karoo Supergroup fluvial strata in the Tuli Basin, South Africa," Journal of African Earth Sciences, vol. 35, no. 4, pp. 503-521, 2002.

[13] R. M. Flores, "Coal deposition in fluvial paleoenvironments of the paleocene tongue river member of the fort union formation, powder river area, powder river basin, wyoming and montana," in Recent and Ancient Non-Marine Depositional Environments: Models for Exploration, F. G. Ethridge and R. M. Flores, Eds., vol. 31, pp. 169-190, SEPM Special Publications, 1981.

[14] C. F. K. Diessel, Coal-Bearing Depositional Systems, Springer, Berlin, Germany, 1992.

[15] E. M. Bordy and O. Catuneanu, "Sedimentology of the upper Karoo fluvial strata in the Tuli Basin, South Africa," Journal of African Earth Sciences, vol. 33, no. 3-4, pp. 605-629, 2001. 

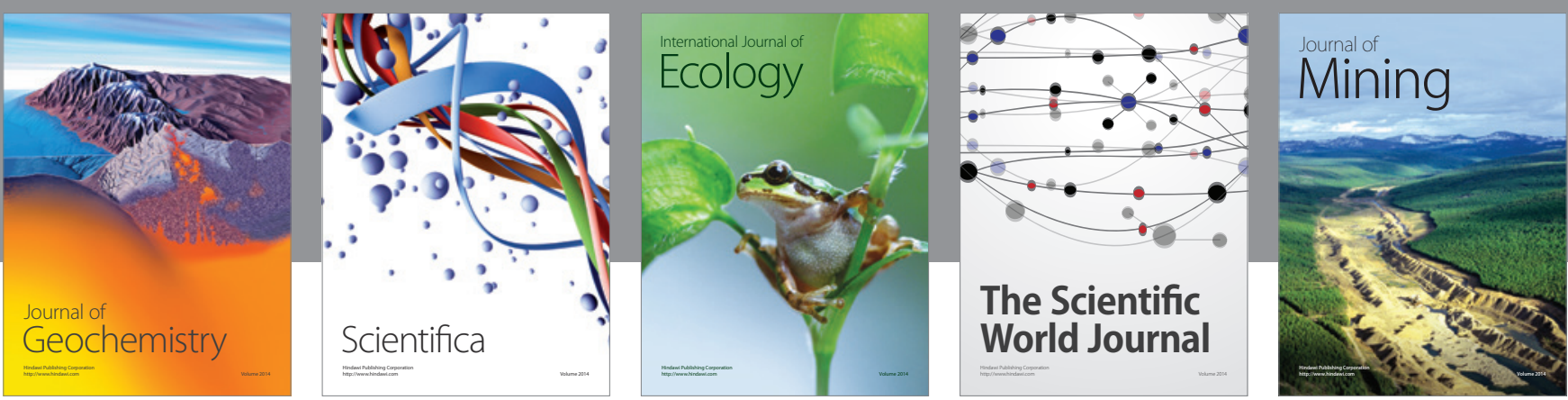

The Scientific World Journal
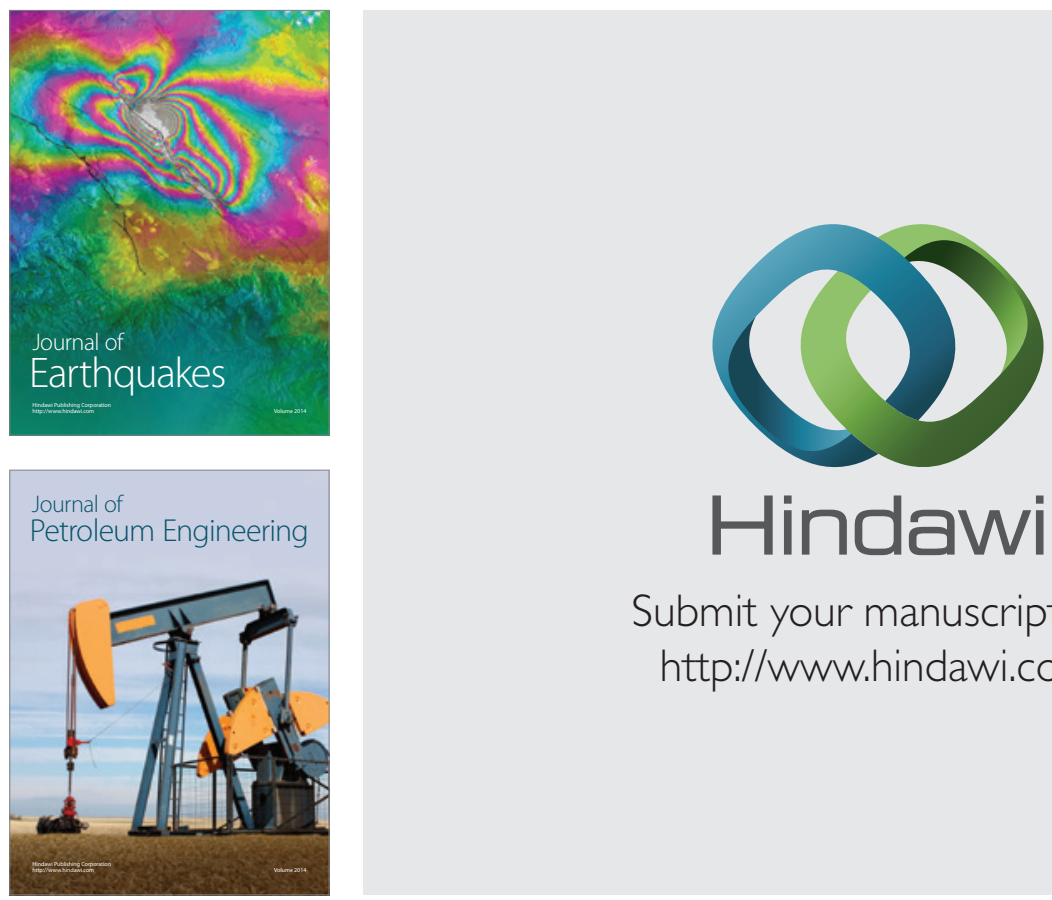

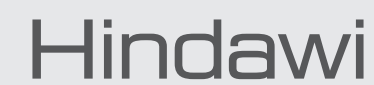

Submit your manuscripts at

http://www.hindawi.com
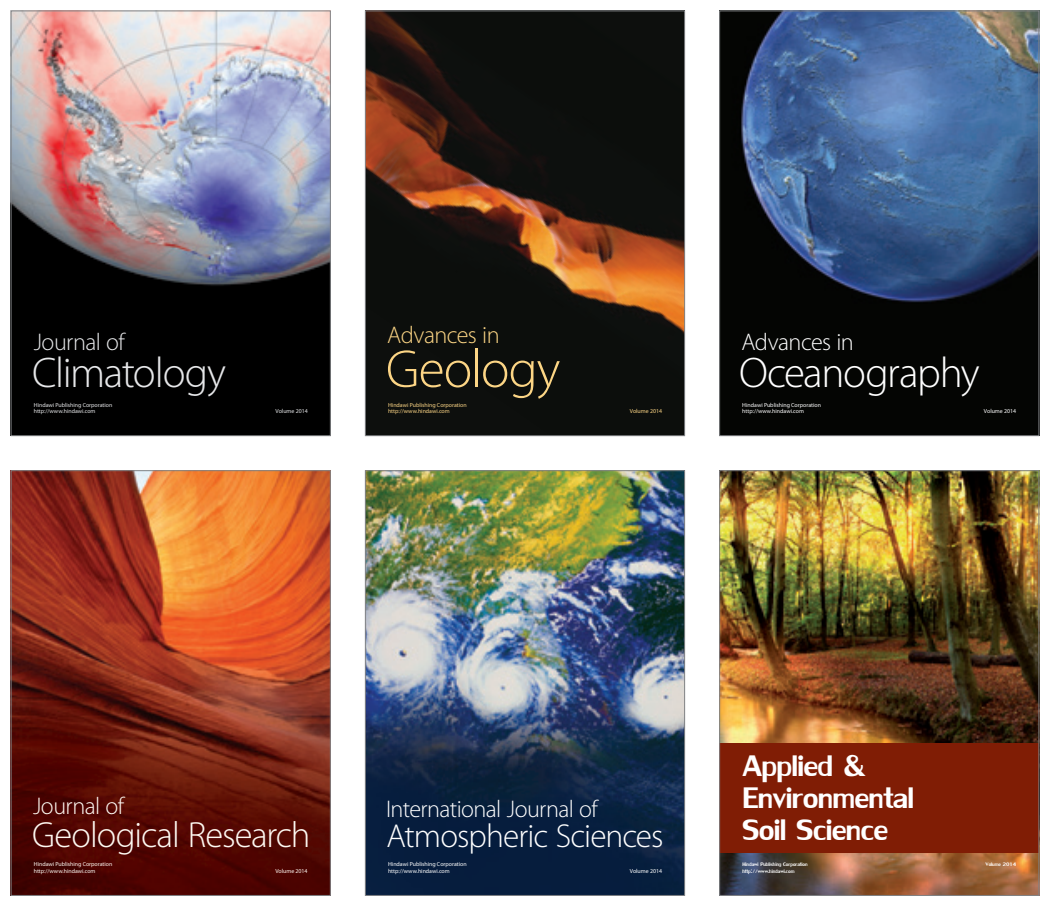
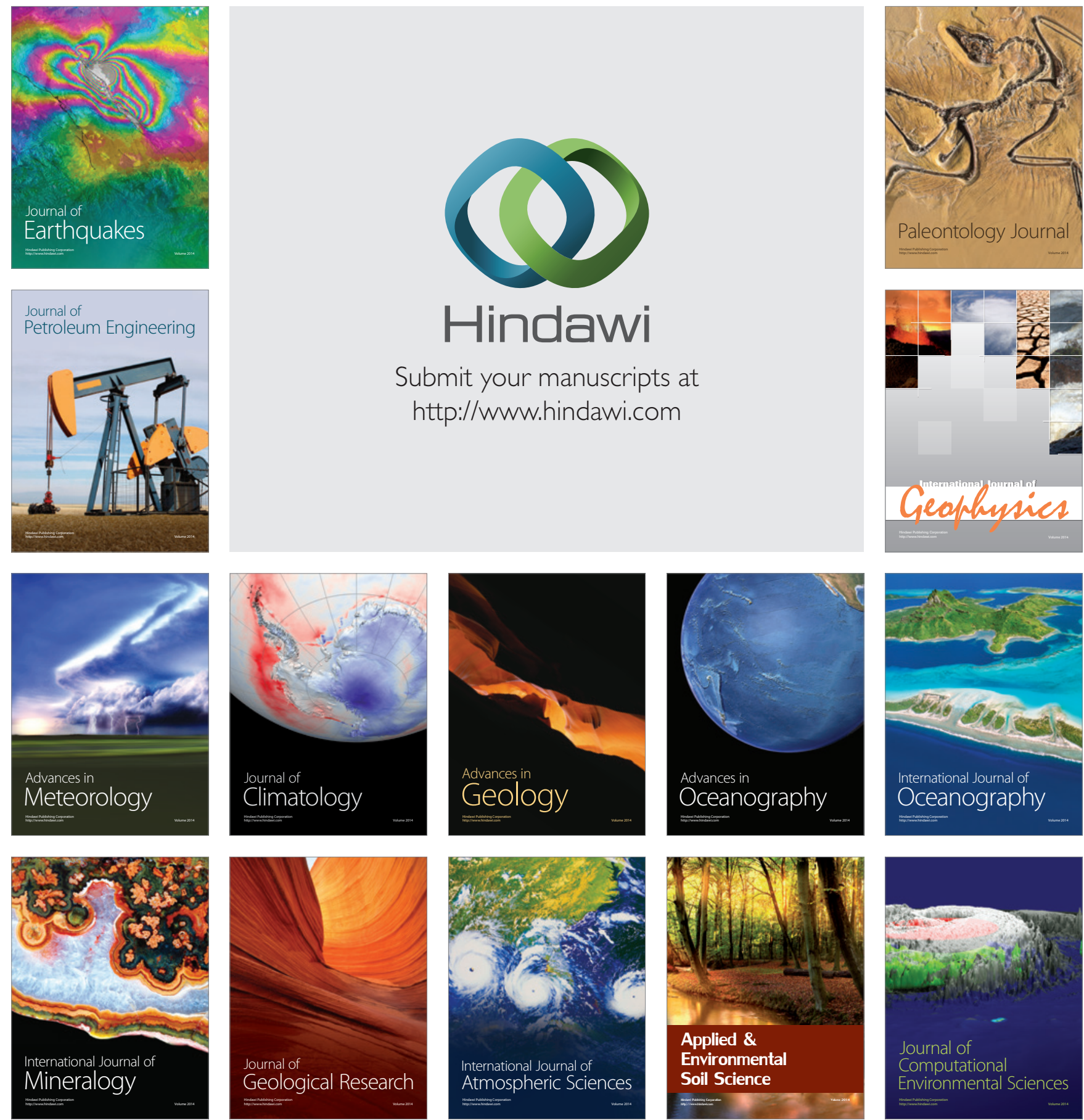